\title{
CONSENSUS OF PUBLIC HEALTH \\ PROFESSORS ON THE MAIN \\ PEDAGOGICAL APPROACHES \\ FOR TRAINING IN THE BRAZILIAN \\ UNIFIED HEALTH SYSTEM
}

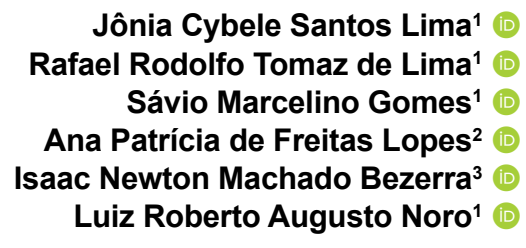

Universidade Federal do Rio Grande do Norte, Centro de Ciências da Saúde, Programa de Pós-Graduação em Saúde Coletiva. Natal, Rio Grande do Norte, Brasil. ${ }^{2}$ Universidade Federal do Rio Grande do Norte, Centro de Ciências da Saúde, Departamento de Odontologia. Natal, Rio Grande do Norte, Brasil. ${ }^{3}$ Universidade Federal de Pernambuco, Programa de Residência Multiprofissional de Interiorização de Atenção à Saúde. Vitória de Santo Antão, Pernambuco, Brasil.

\begin{abstract}
Objective: to establish consensus from experts on the essential elements for training aimed at the Unified Health System (Sistema Único de Saúde), considering public health assumptions and the Brazilian National Curriculum Guidelines (DCN - Diretrizes Curriculares Nacionais).

Method: this is an evaluability assessment carried out with public health professors based on a logical model built with a focus on DCN and on large areas of public health. Criteria matrix validation was performed through Delphi consensus, carried out in three rounds between June and August 2017. The database was built in an Excel spreadsheet and analyzed after each round. At the end of the last round, the database presented its final composition for export to the Stata software, in which statistical analysis was performed.

Results: at the end of three rounds, 18 experts validated the criteria matrix composed of 40 items. The most significant approaches were related to the subdimensions Health care, Popular education, Humanization, Popular participation, Social accountability, and Planning and management.

Conclusion: the validated criteria matrix is characterized as an important instrument for knowledge construction based on a premise that, by taking over the essential skills for training at $\mathrm{DCN}$, the training process may be problematized by all actors involved. The current Brazilian political scenario, crossed by austerity policies that challenge consolidating the main constitutional rights, should serve as encouragement for a professional training aligned with public interests, especially DCN, in health courses.
\end{abstract}

DESCRIPTORS: Professional training. Unified Health System. Educational measurement. Curriculum. Public health. 


\section{CONSENSO DE PROFESSORES DE SAÚDE COLETIVA SOBRE AS PRINCIPAIS ABORDAGENS PEDAGÓGICAS PARA A FORMAÇÃO NO SISTEMA ÚNICO DE SAÚDE}

\section{RESUMO}

Objetivo: estabelecer consenso a partir de especialistas sobre os elementos essenciais para a formação direcionada ao Sistema Único de Saúde, considerando os pressupostos da saúde coletiva e das Diretrizes Curriculares Nacionais.

Método: trata-se de estudo de avaliabilidade, realizado com professores de saúde coletiva a partir de modelo lógico construído com foco nas Diretrizes Curriculares Nacionais e nas grandes áreas da saúde coletiva. Realizou-se validação de Matriz de critérios por meio do consenso de Delfos, realizado em três rodadas ocorridas entre junho e agosto de 2017. O banco de dados foi construído em planilha Excel e analisado após cada uma das rodadas. Ao final da última rodada, o banco de dados apresentou sua composição final para exportação ao software Stata, no qual foi realizada a análise estatística.

Resultados: ao final das três rodadas, 18 especialistas validaram a Matriz de critérios composta por 40 itens. As abordagens mais significativas estiveram relacionadas às subdimensões Atenção à saúde, Educação popular, Humanização, Participação popular, Responsabilidade social e Planejamento e gestão.

Conclusão: a Matriz de critérios validada caracteriza-se como importante ferramenta para construção do conhecimento, partindo da premissa de que, ao se apoderar das competências essenciais à formação no Diretrizes Curriculares Nacionais, o processo formativo poderá ser problematizado por todos os atores envolvidos. O atual cenário político brasileiro, atravessado por políticas de austeridade que desafiam a consolidação dos principais direitos constitucionais, deve servir como estímulo à formação de profissionais alinhados aos interesses públicos, em especial ao Diretrizes Curriculares Nacionais, nos cursos da área da saúde.

DESCRITORES: Formação profissional. Sistema único de saúde. Avaliação educacional. Currículo.

Saúde pública.

\section{CONSENSO DE LOS PROFESORES DE SALUD PÚBLICA SOBRE LOS PRINCIPALES ENFOQUES PEDAGÓGICOS DE LA FORMACIÓN EN EL SISTEMA ÚNICO DE SALUD BRASILEÑO}

\section{RESUMEN}

Objetivo: establecer consensos de expertos sobre los elementos esenciales para la formación dirigida al Sistema Único de Salud (Sistema Único de Saúde), considerando los supuestos de salud colectiva y los Lineamientos Curriculares Nacionales (DCN - Diretrizes Curriculares Nacionais).

Método: se trata de un estudio de evaluabilidad, realizado con profesores de salud pública basado en un modelo lógico construido con un enfoque en la DCN y las grandes áreas de la salud pública. La validación de la Matriz de Criterios se realizó mediante el consenso Delphi, realizado en tres rondas entre junio y agosto de 2017. La base de datos se construyó en una hoja de cálculo de Excel y se analizó después de cada ronda. Al final de la última ronda, la base de datos presentó su composición final para exportar al software Stata, en el cual se realizó el análisis estadístico.

Resultados: al final de las tres rondas, 18 especialistas validaron la Matriz de criterios compuesta por 40 ítems. Los enfoques más significativos se relacionaron con las subdimensiones Salud, Educación popular, Humanización, Participación popular, Responsabilidad social y Planificación y gestión.

Conclusión: la matriz de criterios validados se caracteriza por ser una herramienta importante para la construcción del conocimiento, partiendo de la premisa de que, al asumir las competencias esenciales para la formación en los DCN, el proceso de formación puede ser problematizado por todos los actores involucrados. El actual escenario político brasileño, atravesado por políticas de austeridad que desafían la consolidación de los principales derechos constitucionales, debe servir de estímulo para la formación de profesionales alineados con los intereses públicos, especialmente los Lineamientos Curriculares Nacionales, en cursos en el área de salud.

DESCRITPORES: Capacitación profesional. Sistema único de salud. Evaluación educacional. Curriculum. Salud pública. 


\section{INTRODUCTION}

Training health professionals in the Unified Health System (SUS - Sistema Único de Saúde) has proved to be a great challenge, both for Higher Education Institutions (HEls) and for health services. ${ }^{1}$ The Brazilian National Curriculum Guidelines (DCN - Diretrizes Curriculares Nacionais) recommend that undergraduate students in health should be inserted in scenarios of SUS practices, since the approximation between education and health with the reality of communities involved qualifies professional training. ${ }^{2}$

The training process of health professionals in HEls has been developing from different stimuli, considering the several categories in this area. It is expected that graduates meet not only the health system's expectations, but mainly that they reflect and exercise their activities positively in order to correspond to the population's real needs. ${ }^{3}$

A professional training at SUS should include a look at the health-disease process, valuing multiple knowledge. Furthermore, it allows a greater understanding of individuals as singular and multidimensional beings in their concrete context. It is essential that it promotes changes with the conditioning factors and determinants of health and that it is focused on social reality and on an intersectoral action, which improves the population's quality of life. ${ }^{3}$ To this end, it is urgent a training reach committed to SUS, especially from the insertion of students, not only in assistance services, but in all social spaces that are related to health promotion and care. ${ }^{4}$

The Brazilian National Policy for Reorientation of Professional Training in Health (PRÓ-Saúde Política Nacional de Reorientação da Formação Profissional em Saúde) contributed to this approach by defining the integration between teaching and service with an emphasis on Primary Health Care and comprehensiveness in health. Among the strategies under this policy, PRÓ-Saúde allowed advances in allocating resources for courses that were intended to review curricula in the perspective of articulation with SUS. PET-Saúde (Programa de Educação para o Trabalho em Saúde - Education Program for Work in Health) provided effective coordination between students, tutors and preceptors of public health services. ${ }^{5}$

Despite advances, there is still a great challenge in defining a better pedagogical approach that aims at training in SUS and for SUS. The field of knowledge of public health needs to support health practices in their essence, based on the proactive participation of society, allowing the understanding of their health problems and how to look for movements to face these adversities. ${ }^{6}$ Thus, it is possible to see the consolidation of training actions built from a collective consciousness that involve professors, students and society in general. ${ }^{7}$

In this regard, it is beneficial to develop proposals for assessment processes that make it possible to identify, based on the courses, the knowledge of their reality in relation to a training centered on SUS, its main advances and challenges. Seeking to fill this gap, this study aimed to establish consensus from experts on the essential elements for a training directed to SUS, considering public health assumptions and DCN.

\section{METHOD}

An assessment study was developed, formed by a set of procedures that precedes assessment, by means of a systematic and preliminary examination regarding appropriate responses to a given problem situation, which strengthens its adoption in decision-making ${ }^{8}$.

As the first stage of this study, a Logical Model (Figure 1) was built from DCN guidelines, for health training aimed at undergraduate courses in the perspective of problematizing pedagogical approaches and training aimed at SUS. Through a logical model construction, possible constituent elements were raised: the problem, the context, the general objective, the research goals and specific 
objectives to be assessed later. They also covered essential components' needs of health policies and practices in order to produce, in an articulated and integrated way, the necessary results related to health training, from the areas of knowledge of Epidemiology, Health Social Sciences and Policy, Planning and Management aimed at all actors involved in the process.

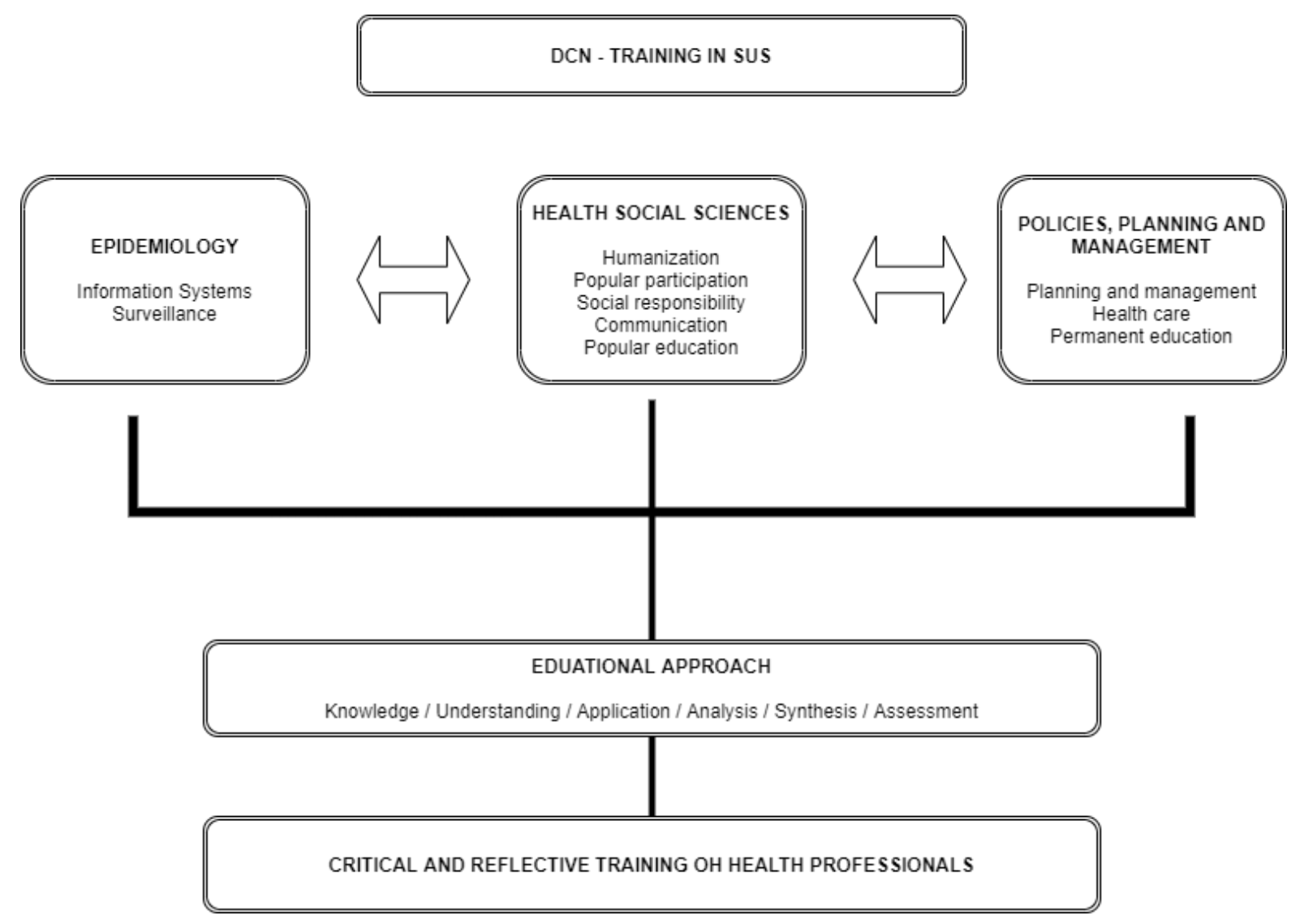

Figure 1 - Logical model built from DCN guidelines for undergraduate courses in health, from the perspective of problematizing pedagogical approaches and training focused on SUS.

In the second stage, a criteria matrix was constructed based on dimensions and subdimensions, which sought to express the expected pattern in the objective image defined in a logical model, based on the following guiding question: what elements are fundamental to train health professionals who come to work in Primary Health Care? To define all dimensions, the three major areas of public health were considered and, for subdimensions, their main areas of operation. Thus, the following configuration was defined: Dimension 1: Epidemiology, with subdimensions 1.1. Information Systems and 1.2. Health Surveillance; Dimension 2: Health Social Sciences, with subdimensions 2.1. Humanization, 2.2. Popular Participation, 2.3. Social Accountability, 2.4. Communication and 2.5. Popular Education; Dimension 3: Policy, Planning and Management, with subdimensions 3.1. Planning and Management, 3.2. Health Care and 3.3. Permanent Education in Health.

Considering the search for plausible relationships between these areas and DCN, the categories of the cognitive domain proposed by Bloom's taxonomy (knowledge, understanding, application, analysis, synthesis, assessment) ${ }^{9}$ were used to compose the criteria to be used in each of subdimensions. Based on a search in the scientific literature and standards present in the logical model, a criteria matrix was created consisting of a total of 62 criteria. 
In order to use the criteria matrix as an instrument for data collection, its validation is essential, developed in the third stage of this study using Delphi Consensus, through three rounds of consultations with experts on the theme ${ }^{10}$; the central campus of Universidade Federal do Rio Grande do Norte (UFRN) was used as a field of study.

The experts selected for this study were public health professors at UFRN from the undergraduate courses in dentistry, nursing, speech therapy, medicine, pharmacy, physiotherapy, nutrition, physical education and public health. The experts' inclusion criteria provided for a minimum master's degree and previous experience in SUS on the condition of having exercised a management role in health services. Based on these criteria, a total of 36 experts were identified through the UFRN faculty portal.

Considering the need to invite a number of experts above the forecast for participation in the rounds, as there are usually dropouts, all identified teachers were invited to participate in Delphi consensus. Data collection was performed by the main researcher of this study. To this end, an invitation letter was sent, via electronic mail, containing aspects such as the study methodological proposal, a logical model, a criteria matrix, in addition to guidelines for the three rounds planned for Delphi consensus development.

For the first round, the criteria matrix was sent with the guidelines related to its completion and requested to be returned within 15 days, considering the number of criteria to be assessed. Among the guidelines, experts were asked to judge a criterion's consistency in relation to the dimension and the sub-dimension to which it was linked, indicating possible suggestions for improvement in writing or even suggestion of new dimensions, new sub-dimensions or new criteria, in a specific field in the matrix itself. In the second step, experts should assess with a score from 0 (zero) to 10 (ten) each of the criteria matrix. Grade 0 meant exclusion from the criterion and grade 10 indicated the maximum importance for a training of health professionals with a focus on SUS.

In the second round, after adjusting the criteria suggested by the experts and signaling the items already validated, the criteria matrix was sent again, requesting the same criteria assessment that were not validated in the first round. A return period of 15 days was also set for this round. In the third round, the procedures were similar to those in the second round, maintaining the same deadline for return. The three rounds that made up Delphi consensus were held between June and August 2017.

A database was built in an excel spreadsheet, in which the analysis was performed after each of the rounds. At the end of the last round, this database presented its final composition to be exported to Stata software, in which statistical analysis was performed. Marks made by experts were analyzed statistically; criteria were considered valid with a median equal to 10 (ten), a mean equal to or greater than 8 (eight), a standard deviation value less than or equal to 3 (three) and a variation coefficient of less than $35 \%$ (thirty-five per percent).

The research project to develop this study was approved by the Research Ethics Committee, in compliance with Resolution 466/2012 of the Brazilian National Health Council (Conselho Nacional de Saúde), ensuring secrecy and confidentiality in relation to the information provided. Experts signed the Informed Consent Form to participate in the study. 


\section{RESULTS}

Of the 36 invited experts, 19 returned their opinions in the first round of Delphi consensus, and 29 criteria were validated in this phase. In the second round, the same 19 experts participated, which validated 6 criteria. In the third round, 18 experts participated, and 5 more criteria were validated. At the end of the three rounds, 40 criteria were validated from the 62 initially proposed. Table 1 presents the results from the dimensions and subdimensions, considering the criteria matrix sent to the experts in the first round, as well as the performance of each criterion after three rounds.

Table 1 - Dimensions, subdimensions and criteria with their mean, standard deviation, median and coefficient of variation after Delphi consensus, per validation round, Natal, RN, Brazil, 2017.

\begin{tabular}{|c|c|c|c|c|c|}
\hline Dimensions & $\mathbf{M}^{*}$ & SD† & Me‡ & CV§ & Roll \\
\hline \multicolumn{6}{|l|}{ Epidemiology dimension } \\
\hline \multicolumn{6}{|l|}{ Information Systems subdimension } \\
\hline Knowledge of information systems & 9.26 & 1.522 & 10 & 16.4 & $1^{\mathrm{a}}$ \\
\hline Health status assessment to guide planning Brazil's health actions & 9.26 & 2.353 & 10 & 25.4 & $1^{\mathrm{a}}$ \\
\hline $\begin{array}{l}\text { Understanding the importance of correct filling out cata } \\
\text { collection instruments and obtaining information } \\
\text { for information system consolidation }\end{array}$ & 8.79 & 2.149 & 10 & 24.4 & $1^{\mathrm{a}}$ \\
\hline $\begin{array}{l}\text { Primary Health Care IHS use to analyze health status, } \\
\text { considering territory's social, economic, demographic } \\
\text { and epidemiological characteristics }\end{array}$ & 8.74 & 2.491 & 10 & 28.5 & $1^{\mathrm{a}}$ \\
\hline Registration of families and individuals in information system & 7.68 & 3.163 & 9 & -- & * \\
\hline $\begin{array}{l}\text { Understanding the concept of health surveillance as a guide } \\
\text { for a health care model }\end{array}$ & 8.68 & 2.562 & 10 & 29.5 & $1^{\mathrm{a}}$ \\
\hline $\begin{array}{l}\text { Development of activities to carry out analysis of population's } \\
\text { health status in the territory in which they operate }\end{array}$ & 8.75 & 2.77 & 10 & 31.4 & $2^{\mathrm{a}}$ \\
\hline \multicolumn{6}{|l|}{ Health Surveillance subdimension } \\
\hline $\begin{array}{l}\text { Understanding about the Brazilian National Health Surveillance } \\
\text { System, its responsibilities and guidelines }\end{array}$ & 8.67 & 2.46 & 10 & 28.3 & $3^{a}$ \\
\hline $\begin{array}{l}\text { Development of skills to perform a population's health status } \\
\text { analysis for action planning, monitoring and assessment }\end{array}$ & 8.44 & 2.872 & 10 & 34 & $3^{a}$ \\
\hline Diagnosis in order to obtain the epidemiological profile & 8.53 & 3.133 & 10 & - - & * \\
\hline Notification of diseases and injuries & 7.89 & 3.23 & 10 & - & * \\
\hline Knowledge of communities's epidemiological profiles & 7.58 & 4.1 & 10 & -- & * \\
\hline Knowledge of risk factors (epidemiological profile) & 7.11 & 4.421 & 10 & -- & * \\
\hline Active search & 7.79 & 3.066 & 8 & -- & * \\
\hline Monitoring of a territory's health status & 6.08 & 4.326 & 7.8 & - & * \\
\hline \multicolumn{6}{|l|}{ Health social and human sciences dimension } \\
\hline \multicolumn{6}{|l|}{ Humanization subdimension } \\
\hline $\begin{array}{l}\text { Assessment of risk stratification and vulnerabilities } \\
\text { during embracement activities }\end{array}$ & 9.53 & 0.87 & 10 & 9.1 & $1^{\mathrm{a}}$ \\
\hline $\begin{array}{l}\text { Knowledge of the Brazilian National Humanization Policy } \\
\text { and its guidelines }\end{array}$ & 9.53 & 1.02 & 10 & 10.7 & $1^{\mathrm{a}}$ \\
\hline $\begin{array}{l}\text { Development of user embracement through qualified listening } \\
\text { of their health needs }\end{array}$ & 8.89 & 2.307 & 10 & 25.9 & $1^{a}$ \\
\hline $\begin{array}{l}\text { Knowledge and applicability of the Brazilian National Humanization } \\
\text { Policy provisions }\end{array}$ & 8.63 & 2.409 & 10 & 27.9 & $1^{\mathrm{a}}$ \\
\hline
\end{tabular}


Table 1 - Cont.

\begin{tabular}{|c|c|c|c|c|c|}
\hline Dimensions & $\mathbf{M}^{*}$ & SD† & Me‡ & CV§ & Roll \\
\hline $\begin{array}{l}\text { Development of listening, understanding and communication } \\
\text { with a community }\end{array}$ & 8.61 & 3.20 & 10 & -- & * \\
\hline Understanding of interactional processes with users & 7.94 & 3.288 & 9 & -- & * \\
\hline \multicolumn{6}{|l|}{ Popular Participation subdimension } \\
\hline Building a bond with community and multidisciplinary team & 9.53 & 0.8 & 10 & 8.4 & $1^{\mathrm{a}}$ \\
\hline Knowledge about popular participation and social control in health & 8.95 & 2.415 & 10 & 26.9 & $1^{\mathrm{a}}$ \\
\hline $\begin{array}{l}\text { Formulation of proposals for effective community } \\
\text { participation in health council }\end{array}$ & 6.79 & 3.881 & 9 & -- & * \\
\hline $\begin{array}{l}\text { Participation in plenary sessions of health councils } \\
\text { and/or health conferences }\end{array}$ & 8.42 & 1.924 & 9 & -- & * \\
\hline $\begin{array}{l}\text { Promotion of mobilization and participation } \\
\text { of a community to effective social control }\end{array}$ & 8.24 & 2.605 & 9 & -- & * \\
\hline Actively act in articulation of a community to participate in health council & 7.37 & 3.148 & 9 & -- & * \\
\hline \multicolumn{6}{|l|}{ Social Accountability subdimension } \\
\hline Knowledge of ethics and bioethics principles & 9.74 & 0.806 & 10 & 8.3 & $1^{\mathrm{a}}$ \\
\hline $\begin{array}{l}\text { Understanding citizenship as a condition of an individual } \\
\text { who lives according to a set of statutes belonging to a political } \\
\text { and socially articulated community }\end{array}$ & 9.63 & 0.684 & 10 & 7.1 & $1^{\mathrm{a}}$ \\
\hline Act respecting criteria deliberated by a group or team & 8.63 & 2.753 & 10 & 31.9 & $1^{\mathrm{a}}$ \\
\hline $\begin{array}{l}\text { Practice of ethics linked to principles of equality, justice, benevolence } \\
\text { and non-malevolence in health decision-making processes }\end{array}$ & 8.89 & 2.56 & 10 & 28.7 & $3^{a}$ \\
\hline $\begin{array}{l}\text { Understanding bioethics as a systematic study } \\
\text { of human conduct in the health field }\end{array}$ & 8 & 3.667 & 10 & -- & * \\
\hline \multicolumn{6}{|l|}{ Communication subdimension } \\
\hline Perception of interests of different social groups & 8.79 & 2.299 & 10 & 26.1 & $1^{a}$ \\
\hline $\begin{array}{l}\text { Develop social strategies and technologies for community } \\
\text { involvement to develop health actions }\end{array}$ & 8.75 & 2.427 & 10 & 27.7 & $1^{\mathrm{a}}$ \\
\hline Knowledge of community language & 8.42 & 2.795 & 10 & 33.1 & $1^{a}$ \\
\hline Listening, understanding and communication practice & 8.58 & 3.115 & 10 & -- & * \\
\hline Use of clear and accessible language & 7.79 & 3.75 & 10 & - & * \\
\hline \multicolumn{6}{|l|}{ Popular Education subdimension } \\
\hline $\begin{array}{l}\text { Realization of health education actions directed } \\
\text { to the enrolled population }\end{array}$ & 9.63 & 0.831 & 10 & 8.6 & $1^{a}$ \\
\hline Knowledge of popular health education principles & 9.58 & 1.017 & 10 & 10 & $1^{a}$ \\
\hline Sharing the different knowledge in the community & 8.42 & 3.097 & 10 & -- & * \\
\hline Implement popular health education strategies & 8.34 & 3.118 & 10 & - & * \\
\hline Argumentation and relationship with leaders & 7.74 & 3.347 & 9 & -- & * \\
\hline \multicolumn{6}{|l|}{ Policy, Planning and Management dimension } \\
\hline \multicolumn{6}{|l|}{ Planning and Management subdimension } \\
\hline Knowledge of SUS principles and guidelines & 9.74 & 0.653 & 10 & 6.7 & $1^{a}$ \\
\hline Identification of health care models & 9.68 & 0.82 & 10 & 8.4 & $1^{\mathrm{a}}$ \\
\hline $\begin{array}{l}\text { Knowledge of the historical, political and economic } \\
\text { trajectory of health in Brazil }\end{array}$ & 9.63 & 0.761 & 10 & 7.9 & $1^{\mathrm{a}}$ \\
\hline Knowledge of health planning and management instruments & 9.47 & 0.964 & 10 & 17.1 & $1^{a}$ \\
\hline
\end{tabular}


Table 1 - Cont.

\begin{tabular}{|c|c|c|c|c|c|}
\hline Dimensions & $M^{*}$ & SDt & Me‡ & CV§ & Roll \\
\hline $\begin{array}{l}\text { Assessment of actions defined in the health } \\
\text { planning/management process }\end{array}$ & 9.35 & 0.931 & 10 & 9.9 & $2^{\mathrm{a}}$ \\
\hline Understanding interdisciplinary and team work performance & 9.18 & 2.43 & 10 & 26.4 & $2^{a}$ \\
\hline $\begin{array}{l}\text { Effective participation in planning activities } \\
\text { for actions to be developed in Primary Care }\end{array}$ & 8.94 & 2.436 & 10 & 27.2 & $2^{a}$ \\
\hline $\begin{array}{l}\text { Knowledge of the human resources of an area of activity } \\
\text { and its attributions }\end{array}$ & 8.53 & 2.366 & 9 & -- & * \\
\hline Understanding health work processes & 8.42 & 3.079 & 10 & -- & * \\
\hline \multicolumn{6}{|l|}{ Health Care subdimension } \\
\hline Knowledge of comprehensive Health Care Networks & 9.84 & 0.501 & 10 & 5.1 & $1^{a}$ \\
\hline $\begin{array}{l}\text { Knowledge of the territorialization process } \\
\text { of a BHU team's area of activity }\end{array}$ & 9.58 & 0.902 & 10 & 9.4 & $1^{\mathrm{a}}$ \\
\hline Health care actions according to a local population's health need & 9.32 & 2.311 & 10 & 24.7 & $1^{a}$ \\
\hline Knowledge of lines of care for comprehensive health care & 9.53 & 0.739 & 10 & 7.7 & $1^{\mathrm{a}}$ \\
\hline $\begin{array}{l}\text { Experience of actions developed from lines of care } \\
\text { and comprehensiveness with Family Health teams }\end{array}$ & 9.41 & 0.795 & 10 & 8.5 & $2^{\mathrm{a}}$ \\
\hline $\begin{array}{l}\text { Understanding the importance of performing } \\
\text { population's health care activities }\end{array}$ & 8.92 & 2.35 & 10 & 26.3 & $3^{a}$ \\
\hline Compression of intersectoriality & 7.79 & 3.584 & 10 & -- & * \\
\hline \multicolumn{6}{|l|}{ Permanent Education in Health subdimension } \\
\hline $\begin{array}{l}\text { Knowledge of the Brazilian National Policy } \\
\text { of Permanent Education in Health }\end{array}$ & 9.32 & 1.057 & 10 & 11.3 & $1^{\mathrm{a}}$ \\
\hline Articulation of different knowledge in a team & 9.11 & 2.331 & 10 & 25.5 & $1^{\mathrm{a}}$ \\
\hline $\begin{array}{l}\text { Development of educational activities based on active } \\
\text { learning methodologies for effective participation } \\
\text { in permanent education activities }\end{array}$ & 9.26 & 1.12 & 10 & 12.1 & $2^{a}$ \\
\hline $\begin{array}{l}\text { Focus on the context of a community, allowing educational } \\
\text { approaches based on health problems experienced in everyday life }\end{array}$ & 9.17 & 2.36 & 10 & 25.7 & $3^{a}$ \\
\hline
\end{tabular}

*criterion not validated; *M: mean; ${ }^{\star} \mathrm{SD}$ : standard deviation; ${ }^{\ddagger} \mathrm{Me}$ : median; ${ }^{\S} \mathrm{CV}$ : coefficient of variation after Delphi consensus; "Ro: validation round; order of the validation round.

There was no change in the writing of the dimensions and subdimensions proposed in the criteria matrix throughout validation. Writing change took place in some criteria. Criteria matrix, defined as a data collection instrument for research that seeks to assess a training focused on SUS, is consolidated in Chart 1. 
Chart 1 - Criteria matrix validated with their respective dimensions and subdimensions, Natal, RN, Brazil, 2017.

\section{DIMENSION 1. EPIDEMIOLOGY}

1.1. Information Systems

Knowledge of information systems

Understanding the importance of correct filling out cata collection instruments

and obtaining information for information system consolidation

Primary Health Care IHS use to analyze health status, considering territory's social,

economic, demographic and epidemiological characteristics

Health status assessment to guide planning Brazil's health actions

1.2. Health Surveillance.

Understanding the concept of health surveillance as a guide for a health care model

Development of skills to perform a population's health status analysis for action planning,

monitoring and assessment

Understanding about the Brazilian National Health Surveillance System, its responsibilities and guidelines Development of activities to carry out analysis of population's health status in the territory in which they operate

\section{DIMENSION 2. HEALTH SOCIAL SCIENCES}

2.1. Humanization

Knowledge of the Brazilian National Humanization Policy and its guidelines

Knowledge and applicability of the Brazilian National Humanization Policy provisions

Development of user embracement through qualified listening of their health needs

Assessment of risk stratification and vulnerabilities during embracement activities

\subsection{Popular participation}

Knowledge about popular participation and social control in health

Building a bond with community and multidisciplinary team

\subsection{Social accountability}

Knowledge of ethics and bioethics principles

Understanding citizenship as a condition of an individual who lives according to a set

of statutes belonging to a political and socially articulated community

Act respecting criteria deliberated by a group or team

Practice of ethics linked to principles of equality, justice, benevolence and non-malevolence

in health decision-making processes

\subsection{Communication}

Knowledge of community language

Perception of the interests of different social groups

Develop social strategies and technologies for community involvement to develop health actions

\subsection{Popular education}

Knowledge of popular health education principles

Realization of health education actions directed to the enrolled population

\section{DIMENSION 3. POLICY, PLANNING AND MANAGEMENT}

3.1. Planning and Management

Knowledge of the historical, political and economic trajectory of health in Brazil

Knowledge of SUS principles and guidelines

Identification of health care models

Knowledge of health planning and management instruments

Understanding the performance of interdisciplinary and multidisciplinary team work

Effective participation in planning activities for actions to be developed in Primary Care

Assessment of actions defined in the health planning/management process 
Chart 1 - Cont.

DIMENSION 3. POLICY, PLANNING AND MANAGEMENT

\subsection{Health Care}

Knowledge of the territorialization process of a BHU team's area of activity

Knowledge of lines of care for comprehensive health care

Knowledge of comprehensive Health Care Networks

Health care actions according to the health needs of the local population

Experience of actions developed from lines of care and comprehensiveness with Family Health teams

Understanding the importance of performing population's health care activities

\subsection{Permanent Education in Health}

Knowledge of the Brazilian National Policy of Permanent Education in Health

Development of educational activities based on active learning methodologies

for effective participation in permanent education activities

Articulation of different knowledge in a team

Focus on the context of a community, allowing educational approaches

based on health problems experienced in everyday life

Regarding the epidemiology dimension and its subdimensions (Health Information and Surveillance System), 8 criteria were validated, 4 in each subdimension. In the Health Social Sciences dimension, 15 criteria were validated, considering the following distribution among the subdimensions: 4 in Humanization, 2 in Popular Participation, 4 in Social Accountability, 3 in Communication and 2 in Popular Education. The Policy, Planning and Management dimension had the highest number of validated criteria, equivalent to 17 criteria in the 3 subdimensions: 7 in Health Planning and Management, 6 in Health Care and 3 criteria in Permanent Health Education.

However, when the criteria with better performance are identified from the mean (above 9.0) and median (equal to 10) and lower dispersion among the experts, through the standard deviation (less than 1) and coefficient of variation (less than 10\%), we observed those that would be the essential elements and of greater importance for the formation, as shown in Table 2.

It should be emphasized that none of the criteria of the Epidemiology dimension was shown to be of essential importance in a training focused on SUS, while the criteria of Planning and Management and Health Care subdimensions of the Policy, Planning and Management dimension and criteria of the Popular Education, Humanization, Popular participation and Social accountability subdimensions of the Health Social Sciences dimension presented this perspective. 
Table 2 - Mean (M), standard deviation (SD), median (Me) and coefficient of variation (CV) of the most significant criteria according to professors' perception, per dimension and subdimensions, Natal, RN, Brazil, 2017.

\begin{tabular}{|c|c|c|c|c|c|}
\hline Subdimension & Criteria & $\mathbf{M}^{*}$ & SD† & Me‡ & CV§ \\
\hline \multicolumn{6}{|c|}{ Policy, Planning and Management dimension } \\
\hline \multirow[t]{4}{*}{ Health Care } & Knowledge of comprehensive Health Care Networks & 9.84 & 0.501 & 10 & 5.1 \\
\hline & $\begin{array}{l}\text { Knowledge of the territorialization process } \\
\text { of a BHU team's area of activity }\end{array}$ & 9.58 & 0.902 & 10 & 9.4 \\
\hline & $\begin{array}{l}\text { Knowledge of lines of care for comprehensive } \\
\text { health care }\end{array}$ & 9.53 & 0.739 & 10 & 7.7 \\
\hline & $\begin{array}{l}\text { Experience of actions developed from lines of care } \\
\text { and comprehensiveness with Family Health teams }\end{array}$ & 9.41 & 0.795 & 10 & 8.5 \\
\hline \multirow[t]{5}{*}{$\begin{array}{l}\text { Planning and } \\
\text { Management }\end{array}$} & Knowledge of SUS principles and guidelines & 9.74 & 0.653 & 10 & 6.7 \\
\hline & Identification of health care models & 9.68 & 0.82 & 10 & 8.4 \\
\hline & $\begin{array}{l}\text { Knowledge of the historical, political and economic } \\
\text { trajectory of health in Brazil }\end{array}$ & 9.63 & 0.761 & 10 & 7.9 \\
\hline & $\begin{array}{l}\text { Assessment of actions defined in the health } \\
\text { planning/management process }\end{array}$ & 9.35 & 0.931 & 10 & 9.9 \\
\hline & Health Social Sciences dimension & & & & \\
\hline \multirow[t]{2}{*}{$\begin{array}{l}\text { Social } \\
\text { Accountability }\end{array}$} & Knowledge of ethics and bioethics principles & 9.74 & 0.806 & 10 & 8.3 \\
\hline & $\begin{array}{l}\text { Understanding citizenship as a condition } \\
\text { of an individual who lives according to a set } \\
\text { of statutes belonging to a political and socially } \\
\text { articulated community }\end{array}$ & 9.63 & 0.684 & 10 & 7.1 \\
\hline $\begin{array}{l}\text { Popular } \\
\text { Education }\end{array}$ & $\begin{array}{l}\text { Realization of health education actions directed } \\
\text { to the enrolled population }\end{array}$ & 9.63 & 0.831 & 10 & 8.6 \\
\hline Humanization & $\begin{array}{l}\text { Assessment of risk stratification and vulnerabilities } \\
\text { during embracement activities }\end{array}$ & 9.53 & 0.87 & 10 & 9.1 \\
\hline $\begin{array}{l}\text { Popular } \\
\text { Participation }\end{array}$ & $\begin{array}{l}\text { Building a bond with community } \\
\text { and multidisciplinary team }\end{array}$ & 9.53 & 0.8 & 10 & 8.4 \\
\hline
\end{tabular}

${ }^{*} \mathrm{M}$ : mean; ${ }^{\mathrm{S} D}$ : standard deviation; ${ }^{\ddagger} \mathrm{Me}$ : median; ${ }^{\circledR} \mathrm{CV}$ : coefficient of variation after Delphi Consensus.

\section{DISCUSSION}

Among the various advances proposed by DCN of courses in health, possibly the biggest challenge remains a training centered on SUS. To meet this challenge, it is essential to learn in curricular components that constitute the field of knowledge and practices of public health. Despite this, due to the breadth and complexity of public health, there is a need to establish a consensus on the educational priorities to be developed in an appropriate training for insertion of graduates in SUS, meeting DCN proposals.

From the perspective of expert professors in public health, this study was configured as a possible way to indicate these pedagogical approaches focused on SUS in undergraduate courses. Therefore, this study has a great contribution to develop an instrument that allows assessment and self-assessment of undergraduate courses. It should be useful to develop evaluability assessment studies that are interested in knowing the current stage of incorporating training in SUS, either by comparing different undergraduate courses or by the perception of students about this stage. In the 
perspective of self-assessment, such an instrument can contribute to teachers in reflecting on their pedagogical practices, identifying the most appropriate in public health and to students a greater understanding of all dimensions of their performance in SUS.

Thus, it sought reference in the three major areas of public health, which were configured as dimensions in the proposed logical model. Over the three rounds for validating the criteria matrix, no dimension had a proposal for change by the experts, which sets them up as appropriate references for thinking about articulation of the public health knowledge field. This direction is fundamental to propose the construction of integrated curricula.

The need for teaching in Epidemiology during health training has been evident with an emphasis on understanding the population dynamics, adding strategic planning, geoprocessing and performance indicators to monitor the efficiency, effectiveness and efficacy of health actions provided to the population. ${ }^{11}$ The subdimensions that made up this dimension (Health Surveillance and Information Systems) had 8 (eight) criteria validated by the experts; however, none of them showed essential importance in a training focused on SUS at graduation, as shown in Table 2. This fact draws attention, since Epidemiology is the area responsible for the best academic performance of stricto sensu Graduate Programs (master's and doctoral degrees), and public health is the field with the highest scientific production.

Due to the learning process, based on real practice scenarios, there are proposals in the Health Social Sciences dimension aimed at reflecting on constructing humans inserted in society and their relations with health-disease-care. For professional training focused on the SUS context, experts considered that in the Human and Social Sciences dimension, it is necessary to address content related to humanization, social accountability, popular education and popular participation; they are essential elements for constructing students' learning processes.

Humanization and embracement instruments are important, as they guarantee access to public health services for all. This strategy concerns listening to users' health problems in a qualified way, always giving them an answer to the problem's resolution. Consequently, user embracement must guarantee resolvability, which is the ultimate goal of health work.

Accountability with the health problem goes beyond service itself, as it also concerns the necessary link to service and users. ${ }^{12}$ Incorporating social accountability aims to truly bring the inserted training to health practices in the community, starting to develop with the professionals the mobilizing role of social agents to be built already in their learning process, as it takes for itself the responsibility of emerging social levels that surround health.

With the 2013 Brazilian National Policy on Popular Education in Health, we see mobilizations considering commitment to SUS principles, especially that of social participation. Popular Health Education becomes a political-pedagogical practice centered on reflection and on health promotion, protection and recovery actions, in which the center becomes dialogue. Building individual and collective knowledge of subjects enables them to introduce them into the SUS reality, strengthening social participation in the consolidation and construction of this System. ${ }^{13}$

Population participation is related to social control, which becomes an instrument of democratization, which must seek a series of practices that effect the participation of society in management. ${ }^{14}$

Within the context of the Policy, Planning and Management dimension, experts agreed that in public health training, it is necessary to address issues related to health planning and management, health care and permanent health education (subdimensions), which are essential for student learning. Among the areas of formation and performance of public health, the dimension Policy, Planning and Management is perhaps the one that contemplates more elements applicable daily; knowledge and practices guide to perform situational diagnoses and, consecutively, proposition of interventions in the scope of micro and macro politics. 
The Policy, Planning and Management dimension also brings together great and current challenges for advancement of SUS; health institutions result in complex and comprehensive work environments. One of these challenges is to stimulate the interprofessional relationship, not necessarily developed in undergraduate courses, with professionals who are often unmotivated, either due to working conditions or due to wage devaluation. ${ }^{15}$ It would be essential for these professionals to develop health promotion actions based on comprehensiveness, universality and equity. ${ }^{16}$ This is possibly why it was the dimension with the largest number of criteria considered essential in training (Table 2).

It is observed that, in the Health Care subdimension, the most significant criteria were related to the category of Bloom's cognitive domain related to knowledge of "Comprehensive Health Care Networks (RAS - Rede de Atenção à Saúde)" of "territorialization process of a BHU team's area of activity" and "SUS principles and guidelines", whereas in the category of the cognitive domain of applicability, in "experience of actions developed from lines of care and comprehensiveness with Family Health teams".

To enhance changes in training, as well as in management, work and health care practices, a strong strategy is to strengthen RAS. In Brazil, RAS constitution is foreseen in the legal framework of SUS when the Federal Constitution of 1988 established that public health services should be articulated in a regionalized and hierarchical way. However, it was only in 2010, based on Ordinance 4,279 of the Ministry of Health, that guidelines for RAS implementation were created within the scope of SUS. ${ }^{17}$ For Networks to be effective, it is essential that students understand the logic of territorialization adopted by Family Health Strategy, since primary care is considered the gateway to SUS. ${ }^{18}$

Based on this basis and effective knowledge of SUS principles and guidelines, it would be possible for students to be inserted in public health services. ${ }^{19}$ Another element considered essential by experts is that this knowledge is, throughout training, linked to experience of actions developed from lines of care and comprehensiveness with Family Health teams, allowing progress in relation to articulation with the health service. ${ }^{20}$

In the Planning and Management subdimension, the criteria "knowledge of the historical, political and economic trajectory of health in Brazil" and "identification of health care models" stood out, both in the category of cognitive domain related to knowledge; meanwhile, "assessment of actions defined in the health planning/management process" is characterized by the category of the cognitive domain related to assessment. Students, in addition to knowing SUS, from its historical, political and economic trajectory, need to know the obstacles that exist in the daily life of services; they must be able to manage their work process and the work process of other professionals. To this end, it is essential to understand the different assistance models that were constituted in SUS, making it possible to identify its challenges, which are still present today. 


\section{CONCLUSION}

In place of the flexnerian and biomedical modus operandi, which is still hegemonic in some HEls today, it is essential to consolidate public health precepts that allow greater coherence in the definition of SUS as a privileged field for health education. By involving students and professors, the criteria matrix is characterized as an important instrument for the integration and construction of knowledge based on the transformation of pedagogical practice and reorientation of learning, based on the premise that, by taking over the essential skills for training in SUS, the formative process can be problematized by all actors involved.

The current Brazilian political scenario, crossed by austerity policies that challenge the consolidation of the main constitutional rights, should serve as a stimulus for training professionals in line with public interests. In the health field, this defense must be effective in maintaining SUS as an essential policy to guarantee the right to universal, public and free health for the entire population.

\section{REFERENCES}

1. Moreira COF, Dias MSA. Diretrizes Curriculares na saúde e as mudanças nos modelos de saúde e de educação. ABCS Health Sci [Internet]. 2015 [cited 2019 Aug 22];40(3):300-5. Available from: https://doi.org/10.7322/abcshs.v40i3.811

2. Makuch DMV, Zagonel IPS. Comprehensive care in health teaching: a systematic review. Rev Bras Educ Med [Internet]. 2017 [cited 2019 Aug 22];41(4):515-24. Available from: https://doi. org/10.1590/1981-52712015v41n4rb20170031

3. Luccas DS, Larocca LM, Chaves MMN, Bernardino E. Enfermeiros e o processo de trabalho de um hospital de ensino: implantação do Sistema Único de Saúde. Texto Contexto Enferm [Internet]. 2015 [cited 2020 Mar 18];24(4):959-67. Available from: https://doi.org/10.1590/01040707201500000180014

4. Palmier AC, Amaral JHL, Werneck MAF, Senna MIB, Lucas SD. Participation by dentistry students in the Unified National Health Service: contributions from the Educational Program for Health Work. Rev Bras Educ Med [Internet]. 2012 [cited 2019 Aug 06];36(1):152-57. Available from: https://doi.org/10.1590/S0100-55022012000300022

5. Costa MV, Patrício KP, Câmara AMCS, Azevedo GD, Batista SHSS. Pro-Health and PET-Health as interprofessional education spaces. Interface (Botucatu) [Internet]. 2015 [cited 2019 Aug 06];19(Suppl 1):709-20. Available from: https://doi.org/10.1590/1807-57622014.0994

6. Oliveira MLS, Silva FCS, Brito KJ, Espírito-Santo E. Public health: how graduated student sees training. Rev Saude Desenv [Internet]. 2015 [cited 2019 Aug 06];7(4):78-93. Available from: https://www.uninter.com/revistasaude/index.php/saudedesenvolvimento/article/view/372

7. Nalom DMF, Ghezzi JFSA, Higa EFR, Peres CRFB, Marin MJS. Health education: learning from professional practice. Cien Saude Colet [Internet]. 2016 [cited 2019 Aug 22];21(9):2949-60. Available from: https://doi.org/10.1590/1413-81232018245.04412019

8. Baratieri T, Nicolotti CA, Natal S, Lacerda JT. Evaluability assessment application on health field: an integrative review. Saude Debate [Internet]. 2019 [cited 2019 Aug 22];43(120):240-55. Available from: https://doi.org/10.1590/0103-1104201912018

9. Ferraz APCM, Belhot RV. Bloom's taxonomy and its adequacy to define instructional objective in order to obtain excellence in teaching. Gest Prod [Internet]. 2010 [cited 2019 Aug 06];17(2):42131. Available from: https://doi.org/10.1590/S0104-530X2010000200015 
10. Valdés MG, Marín MS. Empleo del método Delphi en investigaciones sobre salud publicadas en revistas científicas cubanas. Rev Cuba Inf Cienc Salud [Internet]. 2013 [cited 2019 Aug 06];24(2):133-44. Available from: http://scielo.sld.cu/pdf/ics/v24n2/ics04213.pdf

11. Albuquerque $C$, Martins $M$. Indicadores de desempenho no Sistema Único de Saúde: uma avaliação dos avanços e lacunas. Saúde Debate [Internet]. 2017 [cited 2019 Nov 11];41(Spe):11837. Available from https://doi.org/10.1590/0103-11042017s10

12. Ramos EA, Kattah JAR, Miranda LM, Randow R, Guerra VA. Humanization on Primary Health Care. Rev Med Minas Gerais [Internet]. 2018 [cited 2019 Aug 06];28(Suppl 5):e-S280522. Available from: http://www.rmmg.org/numerosanteriores/28

13. Raimondi GA, Paulino DB, Mendes Neto JP, Diniz LF, Rosa GFC, Limirio V Junior, et al. Intersetorialidade e Educação Popular em Saúde: no SUS com as Escolas e nas Escolas com o SUS. Rev Bras Educ Med [Internet]. 2018 [cited 2019 Aug 16];42(2):73-8. Available from: https://doi.org/10.1590/1981-52712015v42n2rb20170043

14. Oliveira PN, Lima MCR. Controle social e transparência na gestão pública: uma análise das ferramentas disponíveis na administração pública no Brasil. Rev Mult Psic [Internet]. 2019 [cited 2020 Mar 20];13(45):563-80. Available from: https://doi.org/10.14295/idonline.v13i45.1762

15. Cardoso MLM, Costa PP, Costa DM, Xavier C, Souza RMP. The National Permanent Health Education Policy in Public Health Schools: reflections from practice. Cien Saude Colet [Internet]. 2017 [cited 2019 Aug 06];22(5):1489-1500. Available from: https://doi.org/10.1590/141381232017225.33222016

16. Machado MH, Ximenes FRG Neto. The Management of Work and Education in Brazil's Unified Health System: thirty years of progress and challenges. Cien Saude Colet [Internet]. 2018 [cited 2019 Aug 06];23(6):1971-80. Available from: https://doi.org/10.1590/1413-81232018236.06682018

17. Arruda C, Lopes SGR, Koerich MHAL, Winck DR, Meirelles BHS, Mello ALSF. Redes de atención a la salud bajo la teoría de la complejidad. Esc Anna Nery [Internet]. 2015 [cited 2019 Aug 06];19(1):169-73. Available from: https://doi.org/10.5935/1414-8145.20150023

18. Olveira MR, Veras RP, Cordeiro HA. A importância da porta de entrada no sistema: o modelo integral de cuidado para o idoso. Physis [Internet]. 2018 [cited 2019 Nov 14];28(4):e280411. Available from: https://doi.org/10.1590/s0103-73312018280411

19. Mattos RA. Princípios do Sistema Único de Saúde (SUS) e a humanização das práticas de saúde. Interface (Botucatu) [Internet]. 2009 [cited 2019 Nov 11];13(Suppl 1):771-80. Available from https://doi.org/10.1590/S1414-32832009000500028

20. Macedo LM, Martin STF. Interdependência entre os níveis de atenção do Sistema Único de Saúde (SUS): significado de integralidade apresentado por trabalhadores da Atenção Primária. Interface (Botucatu) [Internet]. 2014 [cited 2019 Nov 12];18(51):647-60. Available from https://doi.org/10.1590/1807-57622013.0597 


\section{NOTES}

\section{ORIGIN OF THE ARTICLE}

This article is part of the thesis - A Formação Profissional voltada ao Sistema Único de Saúde e as Percepções sobre Conteúdos de Saúde Coletiva, presented to the Graduate Program in Public Health of Universidade Federal do Rio Grande do Norte, in 2019.

\section{CONTRIBUTION OF AUTHORITY}

Study design: Lima JCS, Noro LRA.

Data collection: Lima JCS, Noro LRA, Lima RRT, Gomes SM, Lopes APF, Bezerra INM.

Data analysis and interpretation: Lima JCS, Noro LRA, Lima RRT, Gomes SM, Lopes APF, Bezerra INM. Discussion of results: Lima JCS, Noro LRA, Lima RRT, Gomes SM, Lopes APF, Bezerra INM.

Writing and/or content critical review: Lima JCS, Noro LRA, Lima RRT, Gomes SM, Lopes APF, Bezerra INM.

Final review and approval of the final version: Lima JCS, Noro LRA, Lima RRT, Gomes SM, Lopes APF, Bezerra INM.

\section{APPROVAL OF ETHICS COMMITTEE IN RESEARCH}

Approved by the Ethics Committee in Research with Human Beings of the Universidade Federal do Rio Grande do Norte, under Opinion 1599772, and CAAE 56995516.9.0000.5292.

\section{CONFLICT OF INTEREST}

There is no conflict of interest.

\section{HISTORICAL}

Received: August 22, 2019.

Approved: April 06, 2020.

\section{CORRESPONDING AUTHOR}

Jônia Cybele Santos Lima

joniacybele@yahoo.com.br 